\title{
Secure Image Role in Online Business Competition
}

\author{
Benny Budiawan Tjandrasa \\ Faculty of Economics, Maranatha Christian University, Indonesia \\ benny.tjandrasa@gmail.com
}

\begin{abstract}
Consumer tastes have changed, technology is increasingly sophisticated and communication is no longer constrained by distance and time. Ease and speed of this transaction also support the development of online stores in Indonesia. On the one hand, the presence of online stores has become the main competitor of conventional stores, but on the other hand, the competition between online stores is getting tighter. For this reason, the study discusses several things such as the impact of the development of the industrial revolution on business management from time to time; market potential, benefits and costs of online stores from the perspective of society and government; competition patterns that will be faced between online stores; how do online business site providers survive in the current pattern of competition. This study using exploratory research which aims to photograph developments, market potential, patterns of competition and find ways to survive in online business. Research was conducted by identifying and categorizing previous studies to get various thoughts from previous researchers. Findings of this study showed the potential of the online-store market in Indonesia will grow further along with population growth, but besides the benefits, there are also costs that must be borne by the society and government, for that the government must make strict rules to minimize these losses. Moreover, online-store entrepreneurs must continue to make efficiency while trying to differentiate so that they are not trapped in the pattern of perfect competition market.
\end{abstract}

\section{Article Info}

- Received : March 17, 2019

- Revised : May 9, 2019

- Published : June 18, 2019

- No. Pages : 188-196

- DOI : 10.33019/ijbe.v3i2.163

- JEL : L21, O14

- Keywords : industrial revolution, online store competition, disruption

\section{Introduction}

Technology process in the last three hundred years is marked with various achievements. Starting with revolution industry 1.0, revolution industry 2.0, revolution industry 3.0, until the era of revolution industry 4.0 the achievement was increasingly clear and changing faster. Not long ago when people were still using pay phones with coins, then they switched to pay phones with magnetic cards, the booming of telephone shops in various places, the invention of cellphones, and now almost all adults have used smartphones as sophisticated as personal computers which makes its predecessor obsolete. Now it is very difficult to find a public telephone, as well as a telephone booth. The same thing is being experienced by various shops, 
more and more shops are closed due to losing competition, and the competition they face is not only competition with similar shops, but also with online stores. Consumer tastes have changed, technology is increasingly sophisticated and communication is no longer constrained by distance and time.

Current knowledge development and innovation has resulted in entrepreneurs experiencing a fundamental change in managing their business, known as disruption. This disruption era is characterized by, among other things, the easier and faster financial transactions (Jack \& Suri, 2011). If a decade ago there were still many people who relied on debit cards and automated teller machines in transactions, now the use of debit cards has begun to be shifted by mobilebanking and virtual-banking. The ease and speed of this transaction also support the proliferation of online stores in Indonesia and other parts of the world. On the one hand, the presence of online stores has become the main competitor of conventional stores, but on the other hand competition between online stores will be even tighter, especially with the entry of foreign online stores such as Amazon to Indonesia (Nurfadilah, 2018). Even though they are new players who are not yet experienced in the Indonesian market but with stronger capital, due to high exchange rate differences, it is only a matter of time for them to gain control of the market with more sophisticated technology and stronger capital. For example, in the case of Amazon which will invest in Indonesia, the company only invests USD 1 billion, but in rupiah it will be IDR 14 trillion, assuming the exchange rate is USD $1=$ IDR 14,000. The investment is almost equivalent to the provincial budget of Aceh in 2017 of IDR 14.91 trillion (Firsawan, 2018). To compete for head to head with foreign investors in terms of capital is certainly not a wise thing, especially if it competes technologically because foreign investors will be able to buy the most sophisticated technology with the large capital they have. The problem is whether domestic businessmen will return to being spectators in their own country while Indonesia is one of the world's largest online markets. Realizing the problem, the author is interested in discussing a number of things, namely:

1. The impact of the development of the industrial revolution on business management from time to time.

2. Market potential, benefits and losses of online stores from the perspective of society and government.

3. The pattern of competition that will be faced between online stores.

4. How online business providers can survive in the current pattern of competition?

\section{Literature Reviews}

Preferred Every civilization in every era certainly has a different milestone, for example, the discovery of how to make a fire in prehistoric times, the discovery of wheels in ancient times, the discovery of gunpowder in the ancient Chinese empire, and the discovery of drinking water channels in the days of the ancient Roman empire. Every nation can interpret the achievement of their civilization as a milestone, but not necessarily other nations agree. In the context of Western European and American civilizations, the industrial revolution was marked by different achievements.

\section{Industrial Revolution 1.0}

The first industrial achievement or the industrial revolution 1.0 was marked by the commencement of the use of steam engines for industry, this era lasted from 1784 to 1870 . The 
use of this steam engine changed the pattern of work and trade in Europe which previously relied heavily on animal power, hydropower, wind power, and even human power to move equipment to rely on steam engines produced from steam power (Malm, 2013). However, the application of steam engines to this industry has an impact on the exploitation of natural resources and human resources to pursue the speed of engine production. Many natural resources exploited at that time were coal because water vapour was produced from heated water from the heat energy contained in coal. Because coal mining in the bowels of the earth at that time could not be carried out by machinery, mine workers were also exploited to meet the increasing demand for coal (Rosen, 2010). The use of petroleum at that time was not too much, but it already existed, namely as a lubricant for engine wheel gear. The faster the goods that can be produced have not given consumers the choice to choose a variety of products because the number of supply variations in the product was still relatively small compared to the demand and distribution channels which were generally controlled by the producers so that the producers were still very much in the direction of industrial development. Channels of communication between producers and consumers can be said to have not existed, competition between producers was still not visible because the market was still very broad and open so collaboration between producers was not needed. At this time change can be said to be slow when compared to changes in the present. Education in those days was still very expensive and only for certain groups of people so that many workers were not educated and untrained (Gillard, 2011). Because the minimum age for workers has not been implemented, many school-aged children have worked and the impact of prospective workers was abundant. The abundant supply of prospective workers which was relatively more than the demand for workers makes the company able to reduce workers' wages. On the one hand this made the businessmen increasingly wealthy, but on the other hand, made the workers increasingly exploited.

\section{Industrial Revolution 2.0}

The second industrial revolution known as the Industrial Revolution 2.0 existed in the span of the years 1870 - 1970 with a marker of the achievement of the discovery of the use of electrical energy and conveyor belts (Nof, 2009). Various inventors in the field of electricity include Volta, Ampere, Faraday, Tesla, and Edison. The inventors complemented the previous findings so that electrical energy could be used until now. In this era also found a gasoline engine that at the industrial level was applied together with electrical energy, the impact was that steam engines were replaced by gasoline-powered engines that were relatively smaller and relatively less polluting. The discovery of incandescent lamps by Thomas Alfa Edison also helped change the pattern of work in the community, where workers could more freely work in the company at night and not worry about a fire if the light bulb broke. In this era, there were also innovations in the form of the use of conveyor belts to produce cars and various other products began to be applied. The result is the birth of mass production where the number of products is increasingly abundant in pursuit of the growing needs of the population. First World War and Second World War contributed to mass production (Scott-Kemmis \& Bell, 2010). Both wars have been won by those who can produce weapons, warships, tanks, and planes faster and more. Maybe not many realize that the role of the mass production system is vital in both world wars, but that has been implicit in history. Shifting the use of coal to fuel makes energy costs shift to fuel costs. In this era, there have been limited variations in the number of products so that consumers do not have many choices. Distribution channels are started by distributors and agents, but marketing communications are still one-way, namely from producers to consumers. Competition at the 
industry level began to exist so that several companies began collaborating. Change began to move quickly, also in the community which was marked by the birth of labour laws in the United Kingdom. In this era, new workforce is still quite abundant (Thorpe, 2015).

\section{Industrial Revolution 3.0}

The Industrial Revolution 3.0 existed in the span of 1970 - 2016 with a collection of computer discovery inventions and production automation (Bessen, 2016). Because the price of fuel oil in this era continues to rise, companies are increasingly serious in carrying out energy efficiency and raw material efficiency (Aguiar-Conraria \& Soares, 2011). Product quality and customer loyalty were the company's main goals in this era. Because consumers and customers were the main things, the Consumer Protection Act was born in this era (Waller et al, 2011). The pattern of distribution of goods has been through an outsourcing system, communication with consumers was two-way communication with the establishment of the customer service division. Because of the increasing competition, more and more companies were collaborating to promote the market. Changes that were occurring increasingly were characterized by high labour turnover because various companies are growing rapidly and need immediate labour, hijacking managers and directors were also common in this era (Fujita, 2018). In this era, there was also the demand for emancipation of women's work because more and more female workers were working to meet household needs (Bloom et al, 2009).

\section{Industrial Revolution 4.0}

The term industrial revolution 4.0 was first introduced by Klaus Schwab in the 2016 World Economic Forum. However, the forerunner to the industrial revolution 4.0 began in the early 1990s, when the development of computer and telecommunications technology in the 1990s encouraged the discovery of an international network or better known as internet name (Nigrin, 2014). The launch of a free browser engine from Yahoo.com and Google.com has become the backbone of e-commerce development. Starting with the establishment of Amazon.com, the trade industry using internet media has increasingly spread to various parts of the world. In this industrial revolution 4.0 era, trade competition no longer occurs in physically visible places (shops, malls, and minimarkets) but has penetrated into private spaces through smartphone devices and personal computers (Rüßmann et.al, 2015). The industry can no longer dictate to consumers, on the contrary consumer's dictate industry because competition between industries is very tight, even distribution channels can be chosen by consumers. Technological changes and rapidly changing consumer tastes make competition increasingly fierce, forcing companies to collaborate in order to survive in the industry while providing the best service to consumers by providing security guarantees or known as secure images (Tjandrasa, 2018). Workers who rely on physical and repetitive work are increasingly displaced by machine work, as well as the role of customer service as seen in the banking industry: customer service and tellers are gradually being replaced by machines. On the other hand, prospective workers are increasingly scarce, because many of them choose to become entrepreneurs, even if there are, they are usually fastidious and often come out in a matter of weeks because they feel the condition of the company does not match their dreams.

\section{Table 1. Industrial Revolution}

\begin{tabular}{ll}
\hline Industrial Revolution 1.0 & \\
\hline Birth : 1784 & \\
\hline Milestone & : Steam engine for industry
\end{tabular}


IJBE (Integrated Journal of Business and Economics)

e-ISSN: 2549-3280/p-ISSN: 2549-5933

\begin{tabular}{|c|c|}
\hline Company & : Exploitation of natural resources and human resources \\
\hline Cost & : Energy of coal \& oil \\
\hline Consumer & : There is no choice \\
\hline Channel & : By the manufacturer \\
\hline Communication & : Almost nothing \\
\hline Competitor & : Almost nothing \\
\hline Collaboration & : Almost nothing \\
\hline Change & : Slow \\
\hline Employee & : Not educated/trained \\
\hline New Employee & : Abundant \\
\hline \multicolumn{2}{|c|}{ Industrial Revolution 2.0} \\
\hline Birth & $: 1870$ \\
\hline Milestone & : Electricity and conveyor belts \\
\hline Company & : Mass Production \\
\hline Cost & : Electricity \& fuel oil \\
\hline Consumer & : Not many choices \\
\hline Channel & : Distributor, Agent \\
\hline Communication & : One-way Promotion \\
\hline Competitor & : Start to exist \\
\hline Collaboration & : Start to exist \\
\hline Change & : Fast \\
\hline Employee & : Labor Law was born \\
\hline New Employee & : There are still many \\
\hline \multicolumn{2}{|c|}{ Industrial Revolution 3.0 } \\
\hline Born & $: 1970$ \\
\hline Milestone & : Computer and Automated production \\
\hline Company & : Efficiency, Quality, Customer Loyalty \\
\hline Cost & : Efficiency of electricity \& fuel energy \\
\hline Consumer & : Consumer Protection Law \\
\hline Channel & : Outsourcing \\
\hline Communication & : Customer Service \\
\hline Competitor & : Many \\
\hline Collaboration & : Many \\
\hline Change & : Faster \\
\hline Employee & : Emancipation of Women's Work \\
\hline New Employee & : High Labor Turnover \\
\hline \multicolumn{2}{|c|}{ Industrial Revolution 4.0 } \\
\hline Born & $: 2016$ \\
\hline Milestone & : Interconnection Network on industry \\
\hline Company & : Secure Image \\
\hline Cost & : Sustainable energy \\
\hline Consumer & : Consumers dictate industry \\
\hline Channel & : Consumers who determines \\
\hline Communication & : Customer services start replaced by AI \\
\hline Competitor & : Very many \\
\hline Collaboration & : Must \\
\hline
\end{tabular}




\begin{tabular}{ll}
\hline Change & $:$ Very fast \\
\hline Employee & $:$ Physical and repetitive work is replaced by robots. \\
\hline New Employee & $:$ Rarely, voters, count week resign. \\
\hline
\end{tabular}

\section{Research Methods}

Research design is exploratory research which aims to portray developments, market potential, patterns of competition and find ways to survive online businesses. The research was conducted by identifying and categorizing previous studies to get various thoughts from previous researchers. According to Kuncoro (2011), exploratory research has the main purpose in the form of discovery, in this study the findings are in the form of competition patterns and ways that online businesses can survive. The research approach is qualitative by extracting information from various mass media and literature studies on previous research.

\section{Results}

\section{Market Potential}

According to the latest report from the Indonesian Internet Service Providers Association (APJII), the current population of Indonesia is 262 million people and around 143 million people have been connected to the internet throughout 2017 (Bohang, 2018). Suppose that of the 143 million people who have connected to the internet $50 \%$ of them are active shopping online, meaning that there are around 70 million people. Of the 70 million people, let's say there is an average of IDR 50,000 in funding throughout the year. So, there are around IDR 50,000 times $70,000,000$ customers equal IDR 3,500,000,000,000 funds settle in online businesses. It is predictable that their goal is to get funds that are very abundant and free because there is no need to pay loan interest for that. This is what makes online businesses increasingly attractive to investors. It can be assumed that actually settling funds are the main target of online businesses, not just profits from product sales. This market potential will continue to grow along with the projected increase in Indonesia's population growth (Firmansyah, 2019). But online stores also have their own benefits and costs for society and the government.

\section{Online-Store Benefits and Losses from the Community Perspective}

The costs are borne by consumers to get information on the online market can be very cheap and even zero because someone can simply review on several online store sites on the smartphone they hold. To buy a product, the distance constraints are not an obstacle because someone can buy products from anywhere, but shipping costs are borne by the seller, thus buyers can get the product they want at the lowest price without being constrained by distance or shipping costs. Not all online shop sites offer genuine and quality products, even some online store sites intentionally make promotional items very cheap but do not have the intention to ship the promoted product.

\section{Online-Store Benefits and Losses from the Government Perspective}

Sales of goods at this online store are tax objects for the government and can open employment opportunities such as the package delivery business. The government can lose potential tax revenue for funds to settle in online stores because funds settling in online-stores are categorized as debt and debt is not an object of tax. With funds settling billions of rupiah online-store can lend more funds settles to other institutions with interest that rivals the rates of national banks 
and private banks because online-stores get the funds settled without paying interest. This can be explained by the example of the theory of fraction of money creation.

\section{Example of Fractional Reserve Theory of Money Creation without Online Store Involvement \\ Suppose "A" is buying product from "B" and pay IDR 10 million, then "B" save the money in a private bank. When a customer saves IDR 10 million in cash at a bank money creation has been made because the private bank can be loaned $90 \%$ to others, for instance, "C". While the bank must hold 3\% in bank account and put the rest 7\% in Central Bank of Indonesia.}

\section{Graph 1. Illustration of Fractional Reserve Theory of Money Creation without Online- Store Involvement}

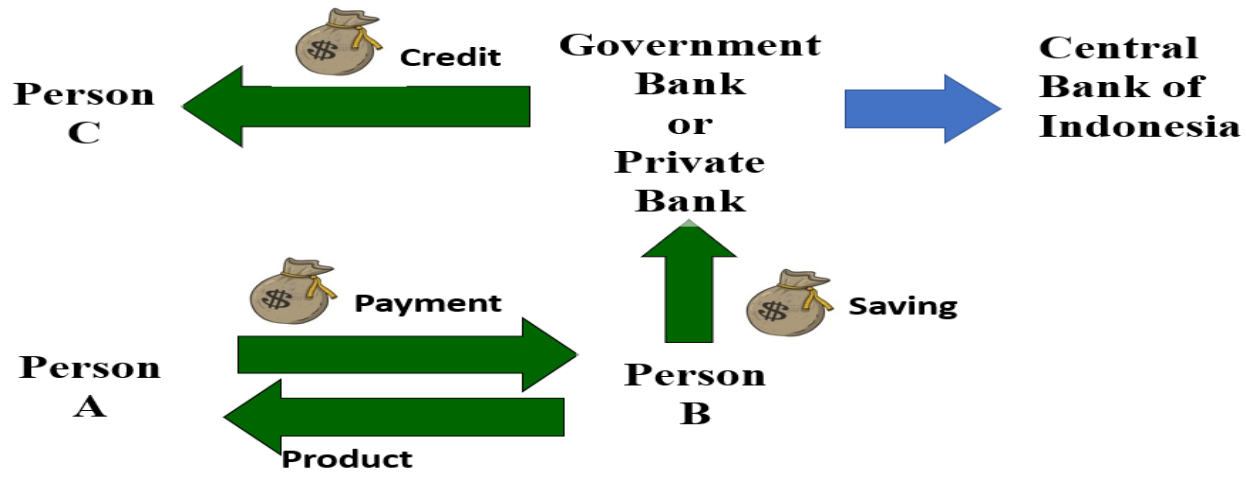

Example of Fractional Reserve Theory of Money Creation with Online Store Involvement Suppose "A" is buying goods from online-store then she must pay it up front, money goes into the account of the online-store site owner, orders received by suppliers, the process of shipping goods on average takes a week to reach the buyer, then when the buyer already stated the item was appropriate and the buyer agreed that the money to be paid to the supplier (in this case is "B") only then the supplier received the money. So, on average there is money settling for a week in an intermediary account, in this case, an online store, and because every day there are transactions like that, based on the calculation above, it can be estimated that there is at least IDR $3,500,000,000,000$ in money that continues to settle in the business account online all year long. With that tax-free money, online businesses can lend funds to banks at the overnight rate.

\section{Graph 2. Illustration of Fractional Reserve Theory of Money Creation with Online Store Involvement}

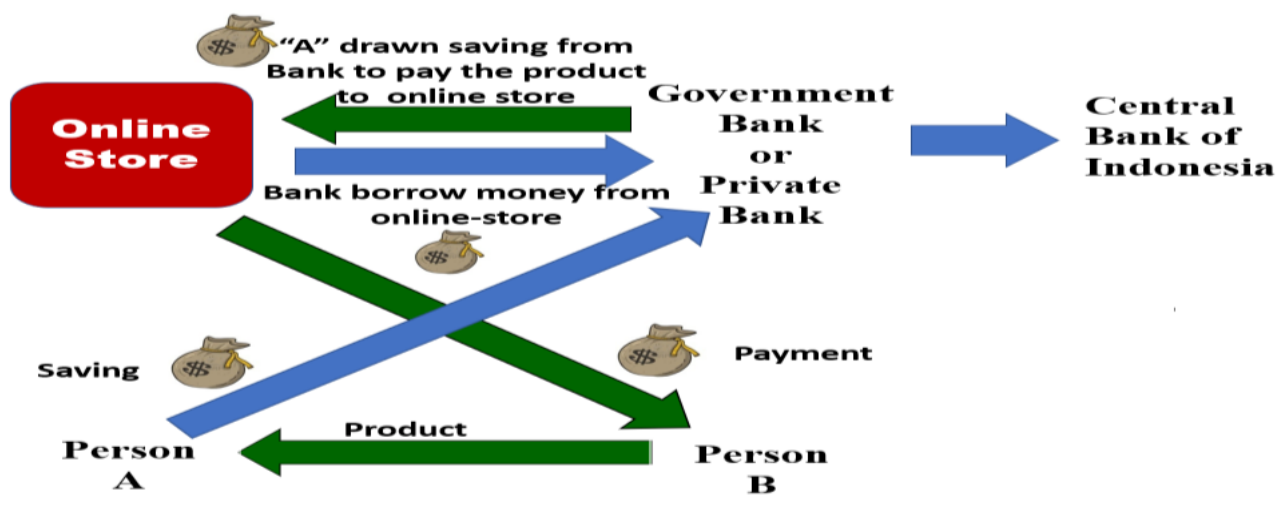




\section{Pattern of Competition That Will Be Faced Between Online Stores}

Today there are more and more online store sites that do business in Indonesia, and more diverse products they sell ranging from prepaid cellphone credit to airline tickets. Competition between online stores does not only occur in similar businesses but also occurs in completely different businesses, for example, the sale of prepaid cellphone credit is not only done by online store sites such as Tokopedia and Bukalapak but is also sold on the Gojek, Ovo, and even in all mobile banking. All online store sites in Indonesia can be said that all sell similar items but at different prices, and not infrequently fake goods are offered at several online store sites so that it will certainly harm the buyer. Many sellers with similar products and many buyers reflect the type of market that has entered the perfect competition market, both between sellers at an online store site or between online store sites such as Tokopedia, Bukalapak, Lazada, Bli Bli and Shopee. When the product offered is similar and the buyer does not feel the difference in buying on any online site, the price will be decisive, for example for cellular telephone pulses, the buyer will not feel the difference in buying anywhere as long as the pulses can be used. In the long run, sellers involved in this perfectly competitive market will have difficulty earning profits. For this reason, we need a way for online site providers to survive in the pattern of competition.

\section{How Online Business Providers Can Survive in the Current Pattern of Competition?}

Besides continuing to make efficiency, one way for entrepreneurs who have businesses in perfect competition markets is to get out of the market by differentiation (D'aveni, 2010). This is also what can be done by online business people to be able to maintain their business. There are various ways to differentiate such as tangibles, empathy, and response speed (Parasuraman, 2010), and there is also a development of the service quality theory, namely secure image (Tjandrasa, 2018). The application of secure image in online business competition is very relevant so that a business can survive. For example, Singapore Airlines has positioned its company as the safest airline, as well as Volvo which positions its products as the safest, most online taxi that offers user safety and definite rates, hydroponic vegetables that position themselves as insecticide-free vegetables, they can apply prices that are higher than competitors' prices and there are still customers who buy their products. This can be done because basically humans are creatures that avoid risk (Mohr et al., 2010) and they are willing to pay a competitive amount of money to avoid these risks.

\section{Conclusion}

Equations The potential of the online-store market in Indonesia will continue to grow along with population growth, but besides the benefits, there are also costs that must be borne by the community and the government. The disadvantage for the community is that not all online store sites offer genuine and quality products, even some online store sites intentionally make promotional prices for cheap goods but do not have the intention to send the promoted product. The disadvantage for the government is the loss of potential tax revenue for funds to settle in online stores because funds settling in online stores are categorized as debt and debt is not an object of tax. For this reason, the government must make strict rules to minimize these losses.

On the other hand, the increasingly fierce competition pattern among national online stores and the threat of the entry of international online stores need to be observed because it can make the Indonesian market potential only enjoyed by foreign business people. For those online-store entrepreneurs must continue to make efficiency while trying to make differentiation so that they 
are not trapped in the pattern of perfect competition market, the way is to make display differentiation, do empathy, implement response speed and provide a secure image to consumers.

\section{References}

1. Aguiar-Conraria, L., \& Soares, M. J. (2011). Oil and the macroeconomy: using wavelets to analyze old issues. Empirical Economics, 40(3), 645-655.

2. Bessen, J. E. (2016). How computer automation affects occupations: Technology, jobs, and skills.

3. Bloom, D. E., Canning, D., Fink, G., \& Finlay, J. E. (2009). Fertility, female labor force participation, and the demographic dividend. Journal of Economic Growth, 14(2), 79-101.

4. D'aveni, R. A. (2010). Hypercompetition. Simon and Schuster.

5. Firsawan, A.H. (2018). Mendagri Sahkan APBD Aceh 2018 Sebesar Rp15,14 Triliun. https://kabar24.bisnis.com/read/20180323/78/753456/mendagri-sahkan-apbd-aceh-2018-sebesarrp1514-triliun

6. Fujita, S. (2018). Declining labor turnover and turbulence. Journal of Monetary Economics.

7. Jack, W., \& Suri, T. (2011). Mobile money: The economics of M-PESA (No. w16721). National Bureau of Economic Research.

8. Kuncoro, M. (2011). Metode Kuantitatif: Teori dan Aplikasi untuk Bisnis \& Ekonomi. Yogyakarta: UPP STIM YKPN.

9. Malm, A. (2013). The origins of fossil capital: From water to steam in the British cotton industry. Historical Materialism, 21(1), 15-68.

10. Mohr, P. N., Biele, G., Krugel, L. K., Li, S. C., \& Heekeren, H. R. (2010). Neural foundations of risk-return trade-off in investment decisions. Neuroimage, 49(3), 2556-2563.

11. Nigrin, T. (2014). Open competition or discrimination on tracks? Examples of anti-competitive behaviour of the Deutsche Bahn. Review of Economic Perspectives, 14(1), 16-33.

12. Nof, S. Y. (2009). Automation: What it means to us around the world. In Springer handbook of automation (pp. 13-52). Springer, Berlin, Heidelberg.

13. Nurfadilah, P.S. (2018). Amazon Akan Investasi di Indonesia, Ini Kata Bos Tokopedia https://ekonomi.kompas.com/read/2018/09/25/183000126/amazon-akan-investasi-di-indonesia-inikata-bos-tokopedia.

14. Parasuraman, A. (2010). Service productivity, quality and innovation: Implications for service-design practice and research. International Journal of Quality and Service Sciences, 2(3), 277-286.

15. Rosen, W. (2010). The most powerful idea in the world: A story of steam, industry, and invention. Random House.

16. Rüßmann, M., Lorenz, M., Gerbert, P., Waldner, M., Justus, J., Engel, P., \& Harnisch, M. (2015). Industry 4.0: The future of productivity and growth in manufacturing industries. Boston Consulting Group, 9.

17. Scott-Kemmis, D., \& Bell, M. (2010). The mythology of learning-by-doing in World War II airframe and ship production. International journal of technological learning, innovation and development, $3(1), 1-35$.

18. Thorpe, A. (2015). A history of the British Labour Party. Palgrave

19. Tjandrasa, B. B. (2018). The influence of secure image, rate and charges, and variation of product towards customer interest in selecting certain banks and the role in net-interest margin in Indonesia. Journal of Economics, Business \& Accountancy Ventura, 21(2), In-Press.

20. Waller, S., Brady, J., Acosta, R. J., \& Fair, J. (2011). Consumer protection in the United States: an overview. 